\title{
A Study of Derivatives Market in India and its Current Position in Global Financial Derivatives Markets
}

\author{
Ms. Shalini H S ${ }^{1}$, Dr. Raveendra P V ${ }^{2}$ \\ ${ }^{I}$ Department of MBA, Krupanidhi School of Management, Bangalore, Karnataka, India. \\ ${ }^{2}$ Department of MBA, M.S.R.I.T, Bangalore, Karnataka, India.
}

\begin{abstract}
The past decade has witnessed the multiple growths in the volume of international trade and business due to the wave of globalization and liberalization all over the world. As a result, the demand for the international money and financial instruments increased significantly at the global level. In this respect, change in exchange rates, interest rates and stock prices of different financial markets have increased the financial risk to the corporate world. Adverse changes in the macroeconomic factors have even threatened the very survival of business world. It is therefore essential to develop a set of new financial instruments known as derivatives in the Indian financial markets, to manage such risk. The basic purpose of these instruments is to provide commitments to prices for future dates for giving protection against adverse movements in future prices, in order to reduce the extent of financial risks. Today, the financial derivatives have become increasingly popular and most commonly used in the world of finance. This has grown with a phenomenal speed all over the world that now it is called as the derivatives revolution. In India, the emergence and growth of derivatives market is relatively a recent phenomenon. Since its inception in June 2000, derivatives market has exhibited exponential growth both in terms of volume and number of contract traded. The market turnover has grown from Rs.2365 Cr. in 2000-2001 to Rs. 26444804.86 Cr. in 2013-14. Within a short span of twelve years, derivatives trading in India has surpassed cash segment in terms of turnover and number of traded contracts. The passed study encompasses in its scope, history, concept, definition, types, features, regulation, market, trend, growth, Future prospects and challenges of derivatives in India and status of Indian derivatives market vis-à-vis global derivative market.

Keywords: Bombay stock exchange, Derivatives, Exchange rate, Forward, Futures, National stock exchange, Notional value underlying asset, Options, Risk management, Swaps.
\end{abstract}

\section{Introduction}

The most significant milestone in financial innovation is achieved with the issuance and trading of derivatives. Along with this positive element, the proponents of derivatives also admit that this term arouses more controversies and most people look at them with suspicion and few would believe that they do contribute to the society's welfare. But the matter of fact is that derivatives are a standard risk management tool that enables risk- sharing and facilitates the efficient allocation of capital to productive investment activities. In this study, we will try and examine the veracity of a few misconceptions that surround derivatives along with their economic benefits.

The present study attempts to discuss the genesis of derivatives trading by tracing its historical development, types, regulation and policy developments, trend \& growth, future prospects and challenges of derivative market in India.

\section{Methodology}

The study is organized into five sections. Section - I deals with the concept, features, definition, types and classification of derivatives. Section - II has been devoted to a discussion of evolution and growth of derivatives market, and regulation and policy development. Section - III discusses the statistical information (data). Section - IV discusses the status of Indian derivative market vis-a-vis global derivative market. The last Section - V specifies summary and concluding remarks.

\section{SECTION-I}

Concept of Financial Derivatives: At present the Indian stock markets are not having any risk hedged instruments that would allow the investors to manage and minimize the risk. In industrialized countries apart from money market and capital market securities, a variety of other securities known as 'derivatives' have now become available for investment and trading. The derivatives originate in mathematics and refer to a variable which has been derived from another variable. A derivative is a financial product which has been derived from another financial product or commodity. The derivatives do not have independent existence without underlying product and market. Derivatives are contracts which are written between two parties for easily marketable 
assets. Derivatives are also known as deferred delivery or deferred payment instruments. Since financial derivatives can be created by means of a mutual agreement, the types of derivative products are limited only by imagination and so there is no definitive list of derivative products.

A derivative is a financial product which has been derived from another financial product or commodity.

D.G. Gardener defined the derivatives as "A derivative is a financial product which has been derived from market for another product."

The securities contracts (Regulation) Act 1956 defines "derivative" as under section 2 (ac). As per this "Derivative" includes

(a) "a security derived from a debt instrument, share, loan whether secured or unsecured, risk instrument or contract for differences or any other form of security."

(b) "a contract which derived its value from the price, or index of prices at underlying securities."

The above definition conveys that the derivatives are financial products. Derivative is derived from another financial instrument/ contract called the underlying. A derivative derives its value from underlying assets.

Accounting standard SFAS133 defines "a derivative instrument is a financial derivative or other contract which will comprise of all three of the following characteristics:

(i) It has one or more underlying asset, and one or more notional amount or payments provisions or both. Those terms determine the amount of the settlement or settlements.

(ii) It requires no initial net investment or an initial net investment that is smaller than would be required for other types of contract that would be expected to have a similar response to changes in market factors.

(iii) Its terms require or permit net settlement. It can be readily settled net by a means outside the contract or it provides for delivery of an asset that puts the recipients in a position not substantially different from net settlement.

From the aforementioned, derivatives refer to securities or to contracts that derive from another whose value depends on another contract or assets. As such the financial derivatives are financial instrument whose prices or values are derived from the prices of other underlying financial instruments or financial assets. The underlying instruments may be an equity share, stock, bond, debenture, Treasury bill, foreign currency or even another derivative asset.

Hence, financial derivatives are financial instruments whose prices are derived from the prices of other financial instruments.

As defined above, its value is entirely derived from the value of the underlying asset. The underlying asset can be securities, commodities, bullion, currency, livestock or anything else. In other way the underlying asset may assume many forms:

(i) Commodities including grain, coffee beans, orange juice;

(ii) Precious metals like gold \& silver;

(iii) Foreign exchange rates or currencies;

(iv) Bonds of different types, including medium to long term negotiable debt, securities issued by governments, companies etc;

(v) Shares and share warrants of companies traded on recognized stock exchanges and stock index;

(vi) Short term securities such as T-bills;

(vii) Over the counter (OTC) money market products such as loans or deposits.

\section{MAJOR PLAYERS IN THE FINANCIAL DERIVATIVES TRADING}

There are three major players in the financial derivatives trading:

1. Hedgers: Hedgers are traders who use derivatives to reduce the risk that they face from potential movements in a market variable and they want to avoid exposure to adverse movements in the price of an asset. Majority of the participants in derivatives market belongs to this category.

2. Speculators: Speculators are traders who buy/sell the assets only to sell/buy them back profitably at a later point in time. They want to assume risk. They use derivatives to bet on the future direction of the price of an asset and take a position in order to make a quick profit. They can increase both the potential gains and potential losses by usage of derivatives in a speculative venture.

3. Arbitrageurs: Arbitrageurs are traders who simultaneously buy and sell the same (or different, but related) assets in an effort to profit from unrealistic price differentials. They attempts to make profits by locking in a riskless trading by simultaneously entering into transaction in two or more markets. They try to earn riskless profit from discrepancies between futures and spot prices and among different futures prices.

\section{USES OF FINANCIAL DERIVATIVES}

Derivatives are supposed to provide some services and these services are used by investors. Some of the uses and applications of financial derivatives can be enumerated as following: 
1. Management of risk: One of the most important services provided by the derivatives is to control, avoid, shift and manage efficiently different types of risk through various strategies like hedging, arbitraging, spreading etc. Derivative assist the holders to shift or modify suitable the risk characteristics of the portfolios. These are specifically useful in highly volatile financial conditions like erratic trading, highly flexible interest rates, volatile exchange rates and monetary chaos.

2. Price discovery: The important application of financial derivatives is the price discovery which means revealing information about future cash market prices through the future market. Derivative markets provide a mechanism by which diverse and scattered opinions of future are collected into one readily discernible number which provides a consensus of knowledgeable thinking.

3. Liquidity and reduce transaction cost : As we see that in derivatives trading no immediate full amount of the transaction is required since most of them are based on margin trading. As a result, large number of traders, speculators, arbitrageurs operates in such markets. So, derivatives trading enhance liquidity and reduce transaction cost in the markets of underlying assets. Measurement of Market: Derivatives serve as the barometers of the future trends in price which result in the discovery of new prices both on the spot and future markets. They help in disseminating different information regarding the future markets trading of various commodities and securities to the society which enable to discover or form suitable or correct or true equilibrium price in the markets. As a result, the assets will be in an appropriate and superior allocation of resources in the society.

4. Efficiency in trading: Financial derivatives allow for free trading of risk components and that leads to improving market efficiency. Traders can use a position in one or more financial derivatives as a substitute for a position in underlying instruments. In many instances, traders find financial derivatives to be a more attractive instrument than the underlying security. This is mainly because of the greater amount of liquidity in the market offered by derivatives as well as the lower transaction costs associated with trading a financial derivative as compared to the costs of trading the underlying instruments in cash market.

5. Speculation and arbitrage: Derivatives can be used to acquire risk, rather than to hedge against risk. Thus, some individuals and institutions will enter into a derivative contract to speculate on the value of the underlying asset, betting that the party seeking insurance will be wrong about the future value of the underlying asset. Speculators look to buy an asset in the future at a low price according to a derivative contract when the future market price is high, or to sell an asset in the future at a high price according to derivative contract when the future market price is low. Individual and institutions may also look for arbitrage opportunities, as when the current buying price of an asset falls below the price specified in a futures contract to sell the asset.

6. Hedging : Hedge or mitigate risk in the underlying, by entering into a derivative contract whose value moves in the opposite direction to their underlying position and cancels part or all of it out. Hedging also occurs when an individual or institution buys an asset and sells it using a future contract. They have access to the asset for a specified amount of time, and can then sell it in the future at a specified price according to the futures contract of course; this allows them the benefit of holding the asset.

7. Price stabilization function: Derivative market helps to keep a stabilizing influence on spot prices by reducing the short term fluctuations. In other words, derivatives reduce both peak and depths and lends to price stabilization effect in the cash market for underlying asset.

8. Gearing of value: Special care and attention about financial derivatives provide leverage (or gearing), such that a small movement in the underlying value can cause a large difference in the value of the derivative.

9. Develop the complete markets : It is observed that derivative trading develop the market towards "complete markets" complete market concept refers to that situation where no particular investors be better of than others, or patterns of returns of all additional securities are spanned by the already existing securities in it, or there is no further scope of additional security.

10. Encourage competition: The derivatives trading encourage the competitive trading in the market, different risk taking preference at market operators like speculators, hedgers, traders, arbitrageurs etc. resulting in increase in trading volume in the country. They also attract young investors, professionals and other experts who will act as catalysts to the growth of financial market.

12. Other uses : The other uses of derivatives are observed from the derivatives trading in the market that the derivatives have smoothen out price fluctuations, squeeze the price spread, integrate price structure at different points of time and remove gluts and shortage in the markets. The derivatives also assist the investors, traders and managers of large pools of funds to device such strategies so that they may make proper asset allocation increase their yields and achieve other investment goals.

\section{TYPES AND CLASSIFICATION OF DERIVATIVES}

There are many ways in which the derivatives can be categorized based on the markets where they trade, based on the underlying asset and based on the product feature etc. some ways of classification are following: 
(1) On the basis of linear and non-linear: On the basis of this classification the financial derivatives can be classified into two big class namely linear and non-linear derivatives:

(a) Linear derivatives: Those derivatives whose Over-the-counter (OTC) traded derivative: These values depend linearly on the underlying's value are called linear derivatives. They are following:

(i) Forwards

(ii) Futures

(iii) Swaps

(b) Non-linear derivatives: Those derivatives whose value is a non-linear function of the underlying are called non-linear derivatives. They are following:

(i) Options

(ii) Convertibles

(iii) Equity linked bonds

(iv) Reinsurance

(2) On the basis of financial and non-financial: On the basis of this classification the derivatives can be classified into two category namely financial derivatives and non-financial derivatives.

(a) Financial derivatives: Those derivatives which are of financial nature are called financial derivatives. They are following:

(i) Forwards

(ii) Futures

(iii) Options

(iv) Swaps

The above financial derivatives may be credit derivatives, forex, currency fixed-income, interest, insider trading and exchange traded.

(b) Non-financial derivatives: Those derivatives which are not of financial nature are called non-financial derivatives. They are following:

(i) Commodities

(ii) Metals

(iii) Weather

(iv) Others

(3) On the basis of market where they trade: On the basis of this classification, the derivatives can be classified into three categories namely; OTC traded derivatives, exchange-traded derivative and common derivative. Derivative contracts are traded (and privately negotiated) directly between two parties, without going through an exchange or other intermediary. The OTC derivative market is the largest market for derivatives and largely unregulated with respect to disclosure of information between parties. They are following:

(i) Swaps

(ii) Forward rate agreements

(iii) Exotic options

(iv) Other exotic derivative

(b) Exchange traded derivative: Those derivative instruments that are traded via specialized derivatives exchange of other exchange. A derivatives exchange is a market where individual trade standardized contracts that have been defined by the exchange. Derivative exchange act as an intermediary to all related transactions and takes initial margin from both sides of the trade to act as a guarantee. They may be followings:

(i) Futures

(ii) Options

(iii) Interest rate

(iv) Index product

(v) Convertible

(vi) Warrants

(vii) Others 
(c) Common derivative: These derivatives are common in nature/trading and classification. They are following:

(i) Forwards

(ii) Futures

(iii) Options

(iv) Binary options

(v) Warrant

(vi) Swaps

The various types of financial derivatives based on their different properties like, plain. Simple or straight forward, composite, joint or hybrid, synthetic, leveraged, mildly leveraged, customized or OTC traded, standardized or organized exchange traded, regulated and unregulated etc. are available in the market.

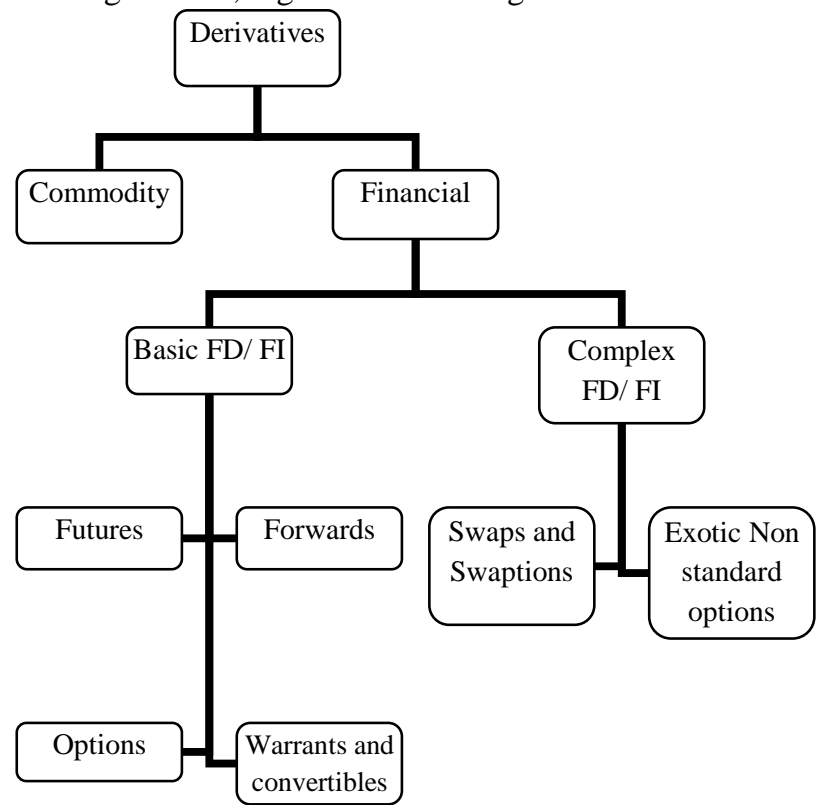

Figure 1: Classification of derivatives

Classification of derivatives contracts in India:

The Indian financial market woke up to the new generation of financial instrument and the Indian derivatives markets' Odyssey in modern times commenced with FOREX derivatives in 1997 has also seen the introduction of many derivatives on different underlying. Currently the following contracts are allowed for trading in Indian markets:

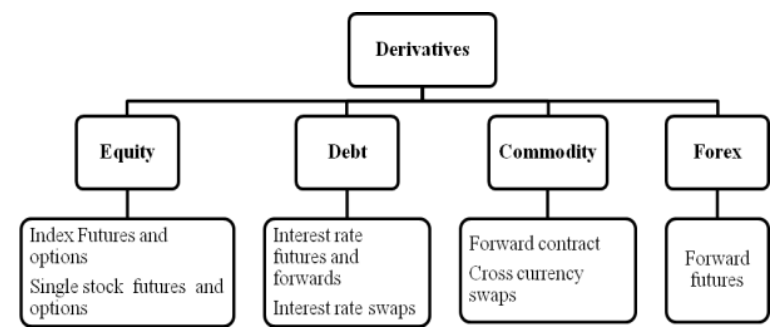

Figure 2: Derivative contracts traded in India

\section{FORWARD CONTRACT}

A forward contract is a customized contract between the buyer and the seller where settlement takes place on a specific date in future at a price agreed today. In case of a forward contract the price which is paid/ received by the parties is decided at the time of entering into contract. It is simplest form of derivative contract mostly entered by individual in day to day life.

The holder of a long (short) forward contract has an agreement to buy (sell) an asset at a certain time in the future for a certain price, which is agreed upon today. The buyer (or seller) in a forward contract: 
- Acquires a legal obligation to buy (or sell) an asset (known as the underlying asset)

- At some specific future date (the expiration date)

- At a price (the forward price) which is fixed today.

The basic features of a contract are given in brief here as under:

1. Forward contracts are bilateral contracts, and hence, they are exposed to the counter party risk. There is risk of non-performance of obligation either of the parties, so these are riskier than to futures contracts.

2. Each contract is custom designed, and hence, is unique in terms of contract size, expiration date, the asset type, quality etc.

3. In forward contract, one of the parties takes a long position by agreeing to buy the asset at a certain specified future date. The other party assumes a short position by agreeing to sell the same asset at the same date for the same specified price. A party with no obligation offsetting the forward contract is said to have an open position. A party with a close position is, sometimes, called a hedger.

4. The specified price in a forward contract is referred to as the delivery price. The forward price for a particular forward contract at a particular time is the delivery price that would apply if the contract were entered into at that time. It is important to differentiate between the forward price and the delivery price. Both are equal at the time the contact is entered into. However, as time passes, the forward price is likely to change whereas the delivery price remains the same.

5. In the forward contract, derivative asset can often be contracted from the combination of underlying assets; such assets are often known as synthetic assets in the forward market.

6. In the forward market, the contract has to be settled by delivery of the asset on expiration date. In case the party wishes to reverse the contract, it has to compulsory go to the same counter party, which may dominate and command the price it wants as being in a monopoly situation.

7. In a forward contract, covered party or cost of carry relations are relation between the prices of forward and underlying assets.

8. Forward contract are very popular in foreign exchange market as well as interest rate bearing instruments. Most of the large and international banks quote the forward rate through their 'forward desk' lying within their foreign exchange trading room. Forward foreign exchange quotes by these banks are displayed with the spot rates.

\section{Futures Contracts}

Futures contract is an agreement between two parties to buy or sell a specified quantity of an asset at a specified price and at a specified time and place. Future contracts are normally traded on an exchange which sets the certain standardized norms for trading in futures contracts. The features of a futures contract may be specified as follows:

1. $\quad$ Futures are traded only in organized exchanges.

2. Futures contract required to have standard contract terms.

3. Futures exchange has associated with clearing house.

4. Futures trading required margin payment and daily settlement.

5. Futures positions can be closed easily.

6. Futures markets are regulated by regulatory authorities like SEBI.

7. The futures contracts are executed on expiry date.

8. The futures prices are expressed in currency units, with a minimum price movement called a tick size. The quality of positive economic theory explains about its ability with precision clarity and simplicity. The main characteristics of futures explained by a good economic theory are as follows:

1. There are a limited number of actively traded products with futures contracts.

2. The trading unit is large and indivisible.

3. It has no more than maturity of 3 months.

4. The success ratio of new contract is about $25 \%$ in the world financial markets.

5. Futures are seldom used by farmers.

6. There are both commercial and non-commercial users of futures contract in interest rates and foreign exchange.

7. The main use of the future by the commercial users is to hedge corresponding cash and forward positions.

8. The positions of the non-commercial users take almost entirely speculative positions.

In foreign exchange futures, the positions of the commercials users are unbalanced. 
There are different types of contracts in financial futures which are traded in the various futures market of the world. The followings are the important types of financial futures contract:

1. Stock future or equity futures

2. Stock index futures

3. Currency futures

4. Interest rate futures

\section{OPTIONS CONTRACTS}

Options are derivative contract that give the right, but not the obligation to either buy or sell a specific underlying security for a specified price on or before a specific date. In theory, option can be written on almost any type of underlying security. Equity (stock) is the most common, but there are also several types of nonequity options, based on securities such as bonds, foreign currency, indices or commodities such as gold or oil. The person who buys an option is normally called the buyer or holder. Conversely, the seller is known as the seller or writer. Again we can say "An option is a particular type of a contract between two parties where one person gives the other person the right to buy or sell a specific asset at a specified price within a specified time period." Today, options are traded on a variety of instruments like commodities, financial assets as diverse as foreign exchange, bank times deposits, treasury securities, stock, stock indexes, petroleum products, food grains, metals etc. The main characteristics of options are following:

1. Options holders do not receive any dividend or interest.

2. $\quad$ Option yield only capital gains.

3. Options holder can enjoy a tax advantages.

4. Options are traded on OTC and in all recognized stock exchanges.

5. Options holders can control their rights on the underlying assets.

6. $\quad$ Options create the possibility of gaining a windfall profit.

7. Options holder can enjoy a much wider risk- return combinations.

8. Options can reduce the total portfolio transaction costs.

9. Options enable with the investors to gain a better returns with a limited amount of investment.

A call which is the right to buy shares under a negotiable contract and which do not carry any obligation. The buyers have the right to receive the delivery of assets are known as 'call option.'

In this option the owner has the right to sell the underlying asset under the negotiable contract. Put option holder has the right to receive the payment by surrendering the asset.

The writer of an option is a stock broker, member or a security dealer. The buyer of an option pays a price depending on the risk of underlying security and he as an investor or a dealer or trader.

The basic features of options or followings:

1. The option is exercisable only by the owner namely the buyer of the option.

2. The owner has limited liability.

3. Owners of options have no voting rights and dividend right.

4. $\quad$ Options have high degree of risk to the option writers.

5. Options involving buying counter positions by the option sellers.

6. Flexibility in investors needs.

7. No certificates are issued by the company.

8. Options are popular because they allow the buyer profits from favorable movement in exchange rate.

Options can be classified into different categories like:

(i) Call options

(ii) Put options

(iii) Exchange traded options

(iv) OTC traded options

(v) American options

(vi) European options

(vii) Commodity options

(viii) Currency options

(ix) Stock options

(x) Stock Index options

\section{SWAPS CONTRACT}

A swap is an agreement between two or more people or parties to exchange sets of cash flows over a period in future.

Swaps are agreements between two parties to exchange assets at predetermined intervals. Swaps are generally customized transactions. The swaps are innovative financing which reduces borrowing costs, and to increase 
control over interest rate risk and FOREX exposure. The swap includes both spot and forward transactions in a single agreement.

Swaps are at the centre of the global financial revolution.

Swaps are useful in avoiding the problems of unfavorable fluctuation in FOREX market. The parties that agree to the swap are known as counter parties. The two commonly used swaps are interest rate swaps and currency swaps.

Interest rate swaps which entail swapping only the interest related cash flows between the parties in the same currency.

Currency swaps entail swapping both principal and interest between the parties, with the cash flows in one direction being in a different currency than the cash flows in the opposite direction.

\section{SECTION - II \\ HISTORICAL DEVELOPMENT OF DERIVATIVE MARKET IN INDIA}

The origin of derivatives can be traced back to the need of farmers to protect themselves against fluctuations in the price of their crop. From the time it was sown to the time it was ready for harvest, farmers would face price uncertainty. Through the use of simple derivative products, it was possible for the farmer to partially or fully transfer price risks by locking-in asset prices. These were simple contracts developed to meet the needs of farmers and were basically a means of reducing risk.

Derivative markets in India have been in existence in one form or the other for a long time. In the area of commodities, the Bombay Cotton Trade Association started future trading way back in 1875. This was the first organized futures market. Then Bombay Cotton Exchange Ltd. in 1893, Gujarat Vyapari Mandall in 1900, Calcutta Hesstan Exchange Ltd. in 1919 had started future market. After the country attained independence, derivative market came through a full circle from prohibition of all sorts of derivative trades to their recent reintroduction. In 1952, the government of India banned cash settlement and options trading, derivatives trading shifted to informal forwards markets. In recent years government policy has shifted in favour of an increased role at market based pricing and less suspicious derivatives trading. The first step towards introduction of financial derivatives trading in India was the promulgation at the securities laws (Amendment) ordinance 1995. It provided for withdrawal at prohibition on options in securities. The last decade, beginning the year 2000, saw lifting of ban of futures trading in many commodities. Around the same period, national electronic commodity exchanges were also set up. The more detail about evolution of derivatives are shown in table No.1 with the help of the chronology of the events.

A Chronology of events: Financial Derivatives in India:

\begin{tabular}{|c|c|c|}
\hline Sl. No. & Progress Date & $\begin{array}{c}\text { Progress of Financial } \\
\text { Derivatives }\end{array}$ \\
\hline 1 & 1952 & $\begin{array}{l}\text { Enactment of the forward } \\
\text { contracts (Regulation) Act. }\end{array}$ \\
\hline 2 & 1953 & $\begin{array}{l}\text { Setting up of the forward market } \\
\text { commission. }\end{array}$ \\
\hline 3 & 1956 & $\begin{array}{l}\text { Enactment of Securities Contract } \\
\text { Regulation Act } 1956\end{array}$ \\
\hline 4 & 1969 & $\begin{array}{l}\text { Prohibition of all forms of } \\
\text { forward trading under section } 16 \\
\text { of SCRA. }\end{array}$ \\
\hline 5 & 1972 & $\begin{array}{l}\text { Informal carry forward trades } \\
\text { between two settlement cycles } \\
\text { began on BSE. }\end{array}$ \\
\hline 6 & 1980 & $\begin{array}{l}\text { Khuso Committee recommends } \\
\text { reintroduction of futures in most } \\
\text { commodities. }\end{array}$ \\
\hline 7 & 1983 & $\begin{array}{l}\text { Govt. amends bye-laws of } \\
\text { exchange of Bombay, Calcutta } \\
\text { and Ahmedabad and introduced } \\
\text { carry forward trading in } \\
\text { specified shares. }\end{array}$ \\
\hline 8 & 1992 & Enactment of the SEBI Act. \\
\hline 9 & 1993 & $\begin{array}{l}\text { SEBI Prohibits carry forward } \\
\text { transactions. }\end{array}$ \\
\hline 10 & 1994 & $\begin{array}{l}\text { Kabra Committee recommends } \\
\text { futures trading in } 9 \text { commodities. }\end{array}$ \\
\hline 11 & 1995 & $\begin{array}{l}\text { G.S. Patel Committee } \\
\text { recommends revised carry } \\
\text { forward system. }\end{array}$ \\
\hline 12 & 14th Dec. 1995 & $\begin{array}{l}\text { NSE asked SEBI for permission } \\
\text { to trade index futures }\end{array}$ \\
\hline
\end{tabular}




\begin{tabular}{|c|c|c|}
\hline 13 & 1996 & $\begin{array}{l}\text { Revised system restarted on } \\
\text { BSE. }\end{array}$ \\
\hline 14 & 18th Nov. 1996 & $\begin{array}{l}\text { SEBI setup LC Gupta committee } \\
\text { to draft frame work for index } \\
\text { futures }\end{array}$ \\
\hline 15 & 11th May 1998 & $\begin{array}{l}\text { LC Gupta committee submitted } \\
\text { report }\end{array}$ \\
\hline 16 & 1st June 1999 & $\begin{array}{l}\text { Interest rate swaps/forward rate } \\
\text { agreements allowed at BSE }\end{array}$ \\
\hline 17 & 7th July 1999 & $\begin{array}{l}\text { RBI gave permission to OTC for } \\
\text { interest rate swaps/forward rate } \\
\text { agreements }\end{array}$ \\
\hline 18 & 24th May 2000 & $\begin{array}{l}\text { SIMEX chose Nifty for trading } \\
\text { futures and options on an Indian } \\
\text { index }\end{array}$ \\
\hline 19 & 25th May 2000 & $\begin{array}{l}\text { SEBI gave permission to NSE \& } \\
\text { BSE to do index futures trading }\end{array}$ \\
\hline 20 & 9th June 2000 & $\begin{array}{l}\text { Equity derivatives introduced at } \\
\text { BSE }\end{array}$ \\
\hline 21 & 12th June 2000 & $\begin{array}{l}\text { Commencement of derivatives } \\
\text { trading (index futures) at NSE }\end{array}$ \\
\hline 22 & 31st Aug. 2000 & $\begin{array}{l}\text { Commencement of trading } \\
\text { futures \& options on Nifty at } \\
\text { SIMEX }\end{array}$ \\
\hline 23 & 1st June 2001 & Index option launched at BSE \\
\hline 24 & Jun 2001 & $\begin{array}{l}\text { Trading on equity index options } \\
\text { at NSE }\end{array}$ \\
\hline 25 & July 2001 & Trading at stock options at NSE \\
\hline 26 & 9th July 2001 & Stock options launched at BSE \\
\hline 27 & July 2001 & $\begin{array}{l}\text { Commencement of trading in } \\
\text { options on individual securities }\end{array}$ \\
\hline 28 & 1st Nov. 2001 & Stock futures launched at BSE \\
\hline 29 & Nov. 2001 & $\begin{array}{l}\text { Commencement of trading in } \\
\text { futures on individual security }\end{array}$ \\
\hline 30 & 9th Nov. 2001 & $\begin{array}{l}\text { Trading of Single stock futures } \\
\text { at BSE }\end{array}$ \\
\hline 31 & June 2003 & $\begin{array}{l}\text { Trading of Interest rate futures at } \\
\text { NSE }\end{array}$ \\
\hline 32 & Aug. 2003 & $\begin{array}{l}\text { Launch of futures \& options in } \\
\text { CNX IT index }\end{array}$ \\
\hline 33 & 13th Sep. 2004 & Weekly options of BSE \\
\hline 34 & June 2005 & $\begin{array}{l}\text { Launch of futures \& options in } \\
\text { Bank Nifty index }\end{array}$ \\
\hline 35 & Dec. 2006 & $\begin{array}{l}\text { Derivative Exchange of the Year } \\
\text { by Asia risk magazine }\end{array}$ \\
\hline 36 & June 2007 & $\begin{array}{l}\text { NSE launches derivatives on } \\
\text { Nifty Junior \& CNX } 100\end{array}$ \\
\hline 37 & Oct. 2007 & $\begin{array}{l}\text { NSE launches derivatives on } \\
\text { Nifty Midcap - } 50\end{array}$ \\
\hline 38 & 1st Jan. 2008 & $\begin{array}{l}\text { Trading of Chhota (Mini) Sensex } \\
\text { at BSE }\end{array}$ \\
\hline 39 & 1st Jan. 2008 & $\begin{array}{l}\text { Trading of mini index futures \& } \\
\text { options at NSE }\end{array}$ \\
\hline 40 & 3rd March 2009 & $\begin{array}{l}\text { Long term options contracts on } \\
\text { S\&P CNX Nifty index }\end{array}$ \\
\hline 41 & NA & $\begin{array}{l}\text { Futures \& options on sectoral } \\
\text { indices ( BSE TECK, BSE } \\
\text { FMCG, BSE Metal, BSE } \\
\text { Bankex \& BSE oil \& gas) } \\
\end{array}$ \\
\hline 42 & 29th Aug. 2008 & $\begin{array}{l}\text { Trading of currency futures at } \\
\text { NSE }\end{array}$ \\
\hline 43 & Aug. 2008 & Launch of interest rate futures \\
\hline 44 & 1st Oct. 2008 & $\begin{array}{l}\text { Currency derivative introduced } \\
\text { at BSE }\end{array}$ \\
\hline 45 & 10th Dec. 2008 & $\begin{array}{l}\text { S\&P CNX Defty futures \& } \\
\text { options at NSE }\end{array}$ \\
\hline 46 & Aug. 2009 & $\begin{array}{l}\text { Launch of interest rate futures at } \\
\text { NSE }\end{array}$ \\
\hline 47 & 7th Aug. 2009 & $\begin{array}{l}\text { BSE-USE form alliance to } \\
\text { develop currency \& interest rate } \\
\text { derivative markets }\end{array}$ \\
\hline 48 & 18th Dec. 2009 & BSE's new derivatives rate to \\
\hline
\end{tabular}




\begin{tabular}{|c|c|c|}
\hline & & lower transaction costs for all \\
\hline 49 & Feb. 2010 & $\begin{array}{l}\text { Launch of currency future on } \\
\text { additional currency pairs at NSE }\end{array}$ \\
\hline 50 & Apr. 2010 & $\begin{array}{l}\text { Financial derivatives exchange } \\
\text { award of the year by Asian } \\
\text { Banker to NSE }\end{array}$ \\
\hline 51 & July 2010 & $\begin{array}{l}\text { Commencement trading of S\&P } \\
\text { CNX Nifty futures on CME at } \\
\text { NSE }\end{array}$ \\
\hline 52 & Oct. 2010 & $\begin{array}{l}\text { Introduction of European style } \\
\text { stock option at NSE }\end{array}$ \\
\hline 53 & Oct. 2010 & $\begin{array}{l}\text { Introduction of Currency options } \\
\text { on USD INR by NSE }\end{array}$ \\
\hline 54 & July 2011 & $\begin{array}{l}\text { Commencement of } 91 \text { day GOI } \\
\text { trading Bill futures by NSE }\end{array}$ \\
\hline 55 & Aug. 2011 & $\begin{array}{l}\text { Launch of derivative on Global } \\
\text { Indices at NSE }\end{array}$ \\
\hline 56 & Sep. 2011 & $\begin{array}{l}\text { Launch of derivative on CNX } \\
\text { PSE \& CNX infrastructure } \\
\text { Indices at NSE }\end{array}$ \\
\hline 57 & 30th March 2012 & $\begin{array}{lr}\text { BSE launched trading in } \\
\text { BRICSMART } & \text { indices } \\
\text { derivatives } & \end{array}$ \\
\hline 58 & $\begin{array}{ll}29^{\text {th }} & \text { November } \\
2013 & \end{array}$ & $\begin{array}{l}\text { BSE launched currency } \\
\text { derivative segment }\end{array}$ \\
\hline
\end{tabular}

\section{REGULATION OF DERIVATIVES TRADING IN INDIA}

The regulatory frame work in India is based on L.C. Gupta Committee report and J.R. Varma Committee report. It is mostly consistent with the international organization of securities commission (IUSCO). The L.C. Gupta Committee report provides a perspective on division of regulatory responsibility between the exchange and SEBI. It recommends that SEBI's role should be restricted to approving rules, bye laws and regulations of a derivatives exchange as also to approving the proposed derivatives contracts before commencement of their trading. It emphasizes the supervisory and advisory role of SEBI. It also suggests establishment of a separate clearing corporation.

\section{DERIVATIVES MARKET IN INDIA}

In India, there are two major markets namely National Stock Exchange (NSE) and Bombay Stock Exchange (BSE) along with other Exchanges of India are the market for derivatives. Here we may discuss the performance of derivatives products in Indian market.

\section{DERIVATIVE PRODUCTS TRADED AT BSE}

The BSE started derivatives trading on June 9, 2000 when it launched "Equity derivatives (Index futures-SENSEX) first time. It was followed by launching various products which are shown in table no.2. They are index options, stock options, single stock futures, weekly options, stocks for: Satyam, SBI, Reliance Industries, Tata Steel, Chhota (Mini) SENSEX, Currency futures, US dollar-rupee future and BRICSMART indices derivatives. The table No.2 summarily specifies the derivative products and their date of introduction at BSE.

\begin{tabular}{|l|l|l|}
\hline Sl. No. & $\begin{array}{l}\text { Date of } \\
\text { commencement }\end{array}$ & Derivatives products \\
\hline 1 & $9^{\text {th }}$ June 2000 & $\begin{array}{l}\text { Equity derivatives (Index } \\
\text { futures - SENSEX) }\end{array}$ \\
\hline 2 & 1 st June 2001 & $\begin{array}{l}\text { Index Options - S\&P CNX } \\
\text { Nifty }\end{array}$ \\
\hline 3 & 9 th July 2001 & $\begin{array}{l}\text { Stock options launched (Stock } \\
\text { option on 109 stocks) }\end{array}$ \\
\hline 4 & 9 th Nov. 2002 & $\begin{array}{l}\text { Stock futures launched (Stock } \\
\text { futures on 109 Stocks) }\end{array}$ \\
\hline 5 & 13 th Sep. 2004 & Weekly options on 4 Stocks \\
\hline 6 & 1st Jan. 2008 & Chhota (mini) SENSEX \\
\hline 7 & NA & $\begin{array}{l}\text { Futures options on sectoral } \\
\text { indices (namely BSE TECK, } \\
\text { BSE FMCG, BSE metal, BSE } \\
\text { Bankex \& BSE oil \& gas) }\end{array}$ \\
\hline 8 & 1 st Oct. 2008 & $\begin{array}{l}\text { Currency derivative introduced } \\
\text { (currency futures on US Dollar) }\end{array}$ \\
\hline 9 & 30th March 2012 & $\begin{array}{l}\text { Launched BRICSMART indices } \\
\text { derivatives }\end{array}$ \\
\hline
\end{tabular}




\section{DERIVATIVE PRODUCTS TRADED AT NSE}

The NSE started derivatives trading on June 12, 2000 when it launched "Index Futures S \& P CNX Nifty" first time. It was followed by launching various derivative products which are shown in table no.3. They are index options, stock options, stock future, interest rate, future CNX IT future and options, Bank Nifty futures and options, CNX Nifty Junior futures and options, CNX100 futures and options, Nifty Mid Cap-50 future and options, Mini index futures and options, Long term options. Currency futures on USD-rupee, Defty future and options, interest rate futures, SKP CNX Nifty futures on CME, European style stock options, currency options on USD INR, 91 days GOI T.B. futures, and derivative global indices and infrastructures indices. The table no.3 presents a description of the types of derivative product traded at NSE and their data of introduction at NSE.

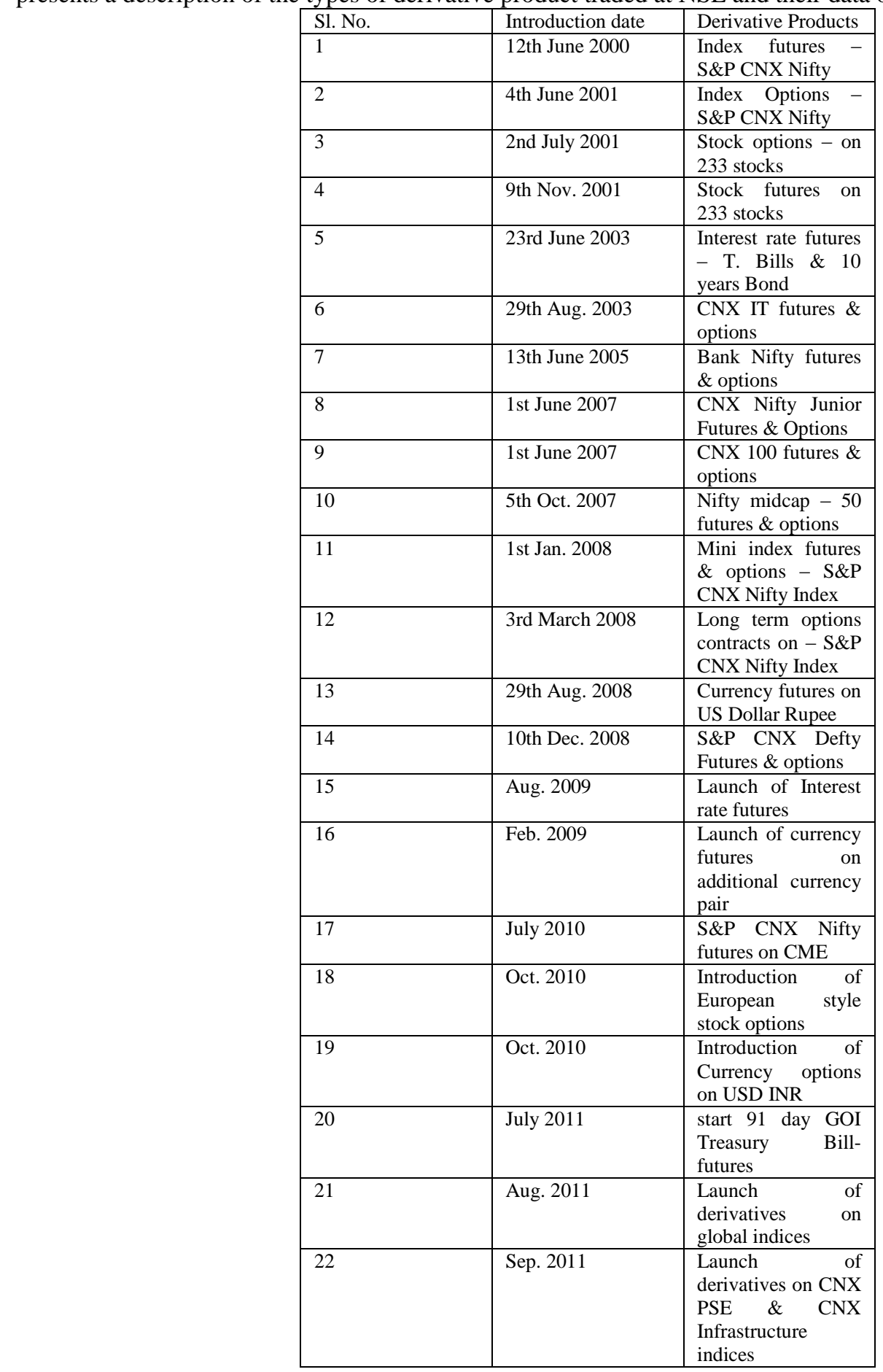




\section{GROWTH OF INDIAN DERIVATIVES MARKET}

The NSE and BSE are two major Indian markets have shown a remarkable growth both in terms of volumes and numbers of traded contracts. Introduction of derivatives trading in 2000, in Indian markets was the starting of equity derivative market which has registered on explosive growth and is expected to continue the same in the years to come. NSE alone accounts $99 \%$ of the derivatives trading in Indian markets. Introduction of derivatives has been well received by stock market players. Derivatives trading gained popularity after its introduction in very short time.

If we compare the business growth of NSE and BSE in terms of number of contracts traded and volumes in all product categories with the help of table no.4, table no.5 and table no.12 which shows the NSE traded 636132957 total contracts whose total turnover is Rs.16807782.22 cr in the year 2012-13 in futures and options segment while in currency segment in 483212156 total contracts have traded whose total turnover is Rs. $2655474.26 \mathrm{cr}$ in same year.

In case of BSE the total numbers of contracts traded are 150068157 whose total turnover is Rs.3884370.96 Cr in the year 2012-13 for all segments. In the above case we can say that the performance of BSE is not encouraging both in terms of volumes and numbers of contracts traded in all product categories. The table no.4, table no.5 and table no.12 summarily specifies the updated figures since 2003-04 to 2012-13 about number of contracts traded and total volumes in all segments.

\begin{tabular}{|l|l|l|l|}
\hline Year & Total No. of Contracts & Total Turnover (Rs. Cr.) & Average Daily Turnover (Rs. Cr.) \\
\hline $2013-2014$ & 911118963 & 26444804.86 & 155557.68 \\
\hline $2012-2013$ & 1131467418 & 31533003.96 & 126638.57 \\
\hline $2011-2012$ & 1205045464 & 31349731.74 & 125902.54 \\
\hline $2010-2011$ & 1034212062 & 29248221.09 & 115150.48 \\
\hline $2009-2010$ & 679293922 & 17663664.57 & 72392.07 \\
\hline $2008-2009$ & 657390497 & 11010482.20 & 45310.63 \\
\hline $2007-2008$ & 425013200 & 13090477.75 & 52153.30 \\
\hline $2006-2007$ & 216883573 & 7356242 & 29543 \\
\hline $2005-2006$ & 157619271 & 4824174 & 19220 \\
\hline $2004-2005$ & 77017185 & 2546982 & 10107 \\
\hline $2003-2004$ & 56886776 & 2130610 & 8388 \\
\hline $2002-2003$ & 16768909 & 439862 & 1752 \\
\hline $2001-2002$ & 4196873 & 101926 & 410 \\
\hline $2000-2001$ & 90580 & 2365 & 11 \\
\hline
\end{tabular}

Source: Compiled from NSE website.

Table 5: Business growth of NSE in CD Segment

\begin{tabular}{|l|l|l|l|}
\hline Year & Total Number of Contracts & Total Turnover (Rs. Crs) & Average Daily Turnover (Rs. Crs) \\
\hline $2013-2014$ & $54,88,48,391$ & $32,94,408.65$ & $19,727.00$ \\
\hline $2012-2013$ & $95,92,43,448$ & $52,74,464.65$ & $21,705.62$ \\
\hline $2011-2012$ & $97,33,44,132$ & $46,74,989.91$ & $19,479.12$ \\
\hline $2010-2011$ & $74,96,02,075$ & $34,49,787.72$ & $13,854.57$ \\
\hline $2009-2010$ & $37,86,06,983$ & $17,82,608.04$ & $7,427.53$ \\
\hline $2008-2009$ & $3,26,72,768$ & $1,62,272.43$ & $1,167.43$ \\
\hline
\end{tabular}

Source: Compiled from NSE website.

\section{SECTION - III}

Statistical data (Information):This section contains the statistical data or information about Indian derivatives markets namely: product wise turnover of FO segment at NSE, product wise turnover of CD segment at NSE, Number of contract traded at NSE in FO segment, number of contracts traded at NSE in CD segment, Average daily transaction at NSE in FO segment, average daily transactions at NSE in CD segment, Product wise turnover of futures at BSE, product wise turnover of options at BSE, number of contract traded at BSE in future segment, number of contract, traded at BSE in option segment and average daily transaction at BSE in all segments.

After analyzing the data given in table no.6, 7, 8, 9, 10,11,13,14,15,16, and 17) we can say that they are encouraging growth and developing. Industry analyst feels that the derivatives market has not yet, realized its full potential in terms of growth and trading. Analyst points out that the equity derivative market on the NSE and BSE has been limited to only four product Index-futures, index options and individual stock future and options, which in turn are limited to certain select stock only. 
Table No. 6: Product wise turnover at NSE

\begin{tabular}{|c|c|c|c|c|c|c|}
\hline Year & $\begin{array}{c}\text { Index Futures } \\
\text { Turnover } \\
(₹ \mathrm{cr})\end{array}$ & $\begin{array}{c}\text { Stock Returns } \\
\text { Turnover } \\
(₹ \mathrm{cr})\end{array}$ & $\begin{array}{c}\text { Index Options } \\
\text { Notional } \\
\text { Turnover } \\
(₹ \mathrm{cr})\end{array}$ & $\begin{array}{c}\text { Stock Options } \\
\text { Notional } \\
\text { Turnover } \\
(₹ \mathrm{cr})\end{array}$ & $\begin{array}{c}\text { Total } \\
\text { Turnover } \\
(₹ \mathrm{cr})\end{array}$ & $\begin{array}{c}\text { Average } \\
\text { Daily } \\
\text { Turnover } \\
(₹ \mathrm{cr})\end{array}$ \\
\hline $2013-14$ & 2176314.26 & 3203112.18 & 19462635.85 & 1602742.62 & 26444804.86 & 155557.68 \\
\hline $2012-13$ & 2527130.76 & 4223872.02 & 22781574.14 & 2000427.29 & 31533003.96 & 126638.57 \\
\hline $2011-12$ & 3577998.41 & 4074670.73 & 22720031.64 & 977031.13 & 31349731.74 & 125902.54 \\
\hline $2010-11$ & 4356754.53 & 5495756.70 & 18365365.76 & 1030344.21 & 29248221.09 & 115150.48 \\
\hline $2009-10$ & 3934388.67 & 5195246.64 & 8027964.20 & 506065.18 & 17663664.57 & 72392.07 \\
\hline $2008-09$ & 3570111.40 & 3479642.12 & 3731501.84 & 229226.81 & 11010482.20 & 45310.63 \\
\hline $2007-08$ & 3820667.27 & 7548563.23 & 1362110.88 & 359136.55 & 13090477.75 & 52153.30 \\
\hline $2006-07$ & 2539574 & 3830967 & 791906 & 193795 & 7356242 & 29543 \\
\hline $2005-06$ & 1513755 & 2791697 & 338469 & 180253 & 4824174 & 19220 \\
\hline $2004-05$ & 772147 & 1484056 & 121943 & 168836 & 2546982 & 10107 \\
\hline $2003-04$ & 554446 & 1305939 & 52816 & 217207 & 2130610 & 8388 \\
\hline $2002-03$ & 43952 & 286533 & 9246 & 100131 & 439862 & 1752 \\
\hline $2001-02$ & 21483 & 51515 & 3765 & 25163 & 101926 & 410 \\
\hline $2000-01$ & 2365 & - & - & - & 2365 & 11 \\
\hline
\end{tabular}

Source: Compiled from NSE website

Table No. 7: Product wise Turnover of CD Segment at NSE

\begin{tabular}{|c|c|c|c|c|}
\hline Year & $\begin{array}{l}\text { Currency Futures } \\
\text { Turnover } \\
(₹ \text { cr.) }\end{array}$ & $\begin{array}{c}\text { Currency Options } \\
\text { Notional Turnover } \\
(₹ \text { cr. })\end{array}$ & $\begin{array}{l}\text { Total Turnover } \\
\quad(₹ \text { cr.) }\end{array}$ & $\begin{array}{c}\text { Average Daily } \\
\text { Turnover } \\
(₹ \text { cr.) }\end{array}$ \\
\hline 2013-2014 & $23,66,882.14$ & $9,27,526.51$ & $32,94,408.65$ & $19,727.00$ \\
\hline $2012-2013$ & $37,65,105.33$ & $15,09,359.32$ & $52,74,464.65$ & $21,705.62$ \\
\hline 2011-2012 & $33,78,488.92$ & $12,96,500.98$ & $46,74,989.91$ & $19,479.12$ \\
\hline $2010-2011$ & $32,79,002.13$ & $1,70,785.59$ & $34,49,787.72$ & $13,854.57$ \\
\hline $2009-2010$ & $17,82,608.04$ & - & $17,82,608.04$ & $7,427.53$ \\
\hline $2008-2009$ & $1,62,272.43$ & - & $1,62,272.43$ & $1,167.43$ \\
\hline
\end{tabular}

Table 8: Number of Contract traded at NSE in FO Segment

\begin{tabular}{|c|c|c|c|c|c|}
\hline Year & $\begin{array}{c}\text { Index Futures } \\
\text { No. of } \\
\text { contracts }\end{array}$ & $\begin{array}{c}\text { Stock Futures } \\
\text { No. of } \\
\text { contracts }\end{array}$ & $\begin{array}{c}\text { Index Options } \\
\text { No. of } \\
\text { contracts }\end{array}$ & $\begin{array}{c}\text { Stock } \\
\text { Options No. } \\
\text { of contracts }\end{array}$ & $\begin{array}{c}\text { Total No. of } \\
\text { contracts }\end{array}$ \\
\hline $2013-14$ & 75537352 & 116676854 & 663033020 & 55871737 & 911118963 \\
\hline $2012-13$ & 96100385 & 147711691 & 820877149 & 66778193 & 1131467418 \\
\hline $2011-12$ & 146188740 & 158344617 & 864017736 & 36494371 & 1205045464 \\
\hline $2010-11$ & 165023653 & 186041459 & 650638557 & 32508393 & 1034212062 \\
\hline $2009-10$ & 178306889 & 145591240 & 341379523 & 14016270 & 679293922 \\
\hline $2008-09$ & 210428103 & 221577980 & 212088444 & 13295970 & 657390497 \\
\hline $2007-08$ & 156598579 & 203587952 & 55366038 & 9460631 & 425013200 \\
\hline $2006-07$ & 81487424 & 104955401 & 25157438 & 5283310 & 216883573 \\
\hline $2005-06$ & 58537886 & 80905493 & 12935116 & 5240776 & 157619271 \\
\hline $2004-05$ & 21635449 & 47043066 & 3293558 & 5045112 & 77017185 \\
\hline $2003-04$ & 17191668 & 32368842 & 1732414 & 5583071 & 56886776 \\
\hline $2002-03$ & 2126763 & 10676843 & 442241 & 3523062 & 16768909 \\
\hline $2001-02$ & 1025588 & 1957856 & 175900 & 1037529 & 4196873 \\
\hline $2000-01$ & 90580 & - & - & - & 90580 \\
\hline
\end{tabular}

Source: Compiled from NSE Website

Table 9: Number of Contract traded at NSE in CD Segment

\begin{tabular}{|c|c|c|c|}
\hline Year & $\begin{array}{c}\text { Currency Futures No. } \\
\text { of contracts }\end{array}$ & $\begin{array}{c}\text { Currency Options } \\
\text { No. of contracts }\end{array}$ & $\begin{array}{c}\text { Total No. of } \\
\text { contracts }\end{array}$ \\
\hline $2013-2014$ & $39,00,52,130$ & $15,87,96,261$ & $54,88,48,391$ \\
\hline $2012-2013$ & $68,41,59,263$ & $27,50,84,185$ & $95,92,43,448$ \\
\hline
\end{tabular}




\begin{tabular}{|c|c|c|c|}
\hline $2011-2012$ & $70,13,71,974$ & $27,19,72,158$ & $97,33,44,132$ \\
\hline $2010-2011$ & $71,21,81,928$ & $3,74,20,147$ & $74,96,02,075$ \\
\hline $2009-2010$ & $37,86,06,983$ & - & $37,86,06,983$ \\
\hline $2008-2009$ & $3,26,72,768$ & - & $3,26,72,768$ \\
\hline
\end{tabular}

Source: Compiled from NSE Website

Table 10: Average daily transaction at NSE in FO Segment

\begin{tabular}{|l|r|r|r|}
\hline Year & $\begin{array}{c}\text { Total No. of } \\
\text { contracts }\end{array}$ & $\begin{array}{c}\text { Total Turnover } \\
(₹) \text { cr.) }\end{array}$ & $\begin{array}{l}\text { Average Daily } \\
\text { Turnover (Rs. } \\
\text { Cr.) }\end{array}$ \\
\hline $2013-14$ & 1279243623 & 38034680.30 & 151532.59 \\
\hline $2012-13$ & 1131467418 & 31533003.96 & 126638.57 \\
\hline $2011-12$ & 1205045464 & 31349731.74 & 125902.54 \\
\hline $2010-11$ & 1034212062 & 29248221.09 & 115150.48 \\
\hline $2009-10$ & 679293922 & 17663664.57 & 72392.07 \\
\hline $2008-09$ & 657390497 & 11010482.20 & 45310.63 \\
\hline $2007-08$ & 425013200 & 13090477.75 & 52153.30 \\
\hline $2006-07$ & 216883573 & 7356242 & 29543 \\
\hline $2005-06$ & 157619271 & 4824174 & 19220 \\
\hline $2004-05$ & 77017185 & 2546982 & 10107 \\
\hline $2003-04$ & 56886776 & 2130610 & 8388 \\
\hline \multicolumn{3}{|c|}{ Source: Compiled from NSE website } \\
\hline
\end{tabular}

Table 11: Average Daily transaction at NSE in CD Segment

\begin{tabular}{|c|c|c|c|}
\hline Year & $\begin{array}{c}\text { Total No. of } \\
\text { contracts }\end{array}$ & $\begin{array}{c}\text { Total } \\
\text { Turnover } \\
(\boldsymbol{₹} \text { cr. })\end{array}$ & $\begin{array}{c}\text { Average } \\
\text { Daily } \\
\text { Turnover } \\
\text { (Rs. Cr. })\end{array}$ \\
\hline $2013-2014$ & $47,83,01,579$ & $29,40,885.92$ & $16,444.73$ \\
\hline $2012-2013$ & $68,41,59,263$ & $37,65,105.33$ & $21,705.62$ \\
\hline $2011-2012$ & $70,13,71,974$ & $33,78,488.92$ & $19,479.12$ \\
\hline $2010-2011$ & $71,21,81,928$ & $32,79,002.13$ & $13,854.57$ \\
\hline $2009-2010$ & $37,86,06,983$ & $17,82,608.04$ & $7,427.53$ \\
\hline $2008-2009$ & $3,26,72,768$ & $1,62,272.43$ & $1,167.43$ \\
\hline
\end{tabular}

Source: Compiled from NSE Website

Table 12: Business growth at BSE in all segments

\begin{tabular}{|c|c|c|c|c|}
\hline Year & Total Contracts & $\begin{array}{c}\text { Total Turnover } \\
\text { (Rs Cr) }\end{array}$ & $\begin{array}{c}\text { Average Daily } \\
\text { Turnover (Rs } \\
\text { Cr) }\end{array}$ & $\begin{array}{c}\text { Trading } \\
\text { Days }\end{array}$ \\
\hline $2013-14$ & 7503405 & 19421854.8 & 308283.4 & 247 \\
\hline $2012-13$ & 150068157 & 3884370.96 & 30828.34 & 241 \\
\hline $2011-12$ & 32222825 & 808475.99 & 3246.89 & 249 \\
\hline $2010-11$ & 5623 & 154.33 & 0.61 & 255 \\
\hline $2009-10$ & 9028 & 234.06 & 1.04 & 224 \\
\hline $2008-09$ & 496502 & 11774.83 & 48.46 & 243 \\
\hline $2007-08$ & 7453371 & 242308.41 & 965.37 & 251 \\
\hline $2006-07$ & 1781220 & 59006.62 & 259.94 & 227 \\
\hline $2005-06$ & 203 & 8.78 & 0.14 & 61 \\
\hline $2004-05$ & 531719 & 16112.32 & 77.09 & 209 \\
\hline $2003-04$ & 143224 & 5021.81 & 81.00 & 62 \\
\hline
\end{tabular}

Source: Compiled from BSE Website

Table 13: Product wise turnover of futures at BSE

\begin{tabular}{|c|c|c|c|}
\hline Year & $\begin{array}{c}\text { Index } \\
\text { Futures } \\
\text { Turnover } \\
\text { (Rs Cr) }\end{array}$ & $\begin{array}{c}\text { Equity } \\
\text { Futures } \\
\text { Turnover } \\
\text { (Rs. Cr.) }\end{array}$ & $\begin{array}{c}\text { Trading } \\
\text { Days }\end{array}$ \\
\hline $2013-14$ & 215647.78 & 32560.80 & 247 \\
\hline $2012-13$ & 194188.65 & 21390.60 & 241 \\
\hline $2011-12$ & 178448.83 & 10215.70 & 249 \\
\hline $2010-11$ & 154.08 & 0.00 & 255 \\
\hline $2009-10$ & 96.00 & 0.30 & 224 \\
\hline $2008-09$ & 11757.22 & 8.49 & 243 \\
\hline $2007-08$ & 234660.16 & 7609.24 & 251 \\
\hline $2006-07$ & 55490.86 & 3515.50 & 227 \\
\hline $2005-06$ & 5.00 & 0.49 & 61 \\
\hline
\end{tabular}




\begin{tabular}{|c|c|c|c|}
\hline $2004-05$ & 13599.66 & 212.85 & 209 \\
\hline $2003-04$ & 3082.63 & 1680.34 & 62 \\
\hline
\end{tabular}

Source: Compiled from BSE Website

Table 14: Product wise turnover of option at BSE

\begin{tabular}{|c|c|c|c|c|c|}
\hline Year & $\begin{array}{l}\text { Index option } \\
\text { Call Turnover } \\
\text { (Rs. Cr.) }\end{array}$ & $\begin{array}{l}\text { Index Option } \\
\text { Put Turnover } \\
\quad \text { (Rs. Cr.) }\end{array}$ & $\begin{array}{c}\text { Equity } \\
\text { Option Call } \\
\text { Turnover } \\
\text { (Rs. Cr.) }\end{array}$ & $\begin{array}{c}\text { Equity } \\
\text { option Put } \\
\text { Turnover } \\
\text { (Rs. Cr.) } \\
\end{array}$ & Trading days \\
\hline 2013-14 & 17680872.23 & 9063791.85 & 1487.98 & 298.54 & 247 \\
\hline $2012-13$ & 1967091.23 & 1812758.37 & 1367.87 & 245.32 & 241 \\
\hline $2011-12$ & 200089.57 & 418252.79 & 1277.27 & 191.82 & 249 \\
\hline $2010-11$ & 0.00 & 0.25 & 0.00 & 0.00 & 255 \\
\hline 2009-10 & 137.76 & 0.00 & 0.00 & 0.00 & 224 \\
\hline $2008-09$ & 6.11 & 3.01 & 0.00 & 0.00 & 243 \\
\hline 2007-08 & 31.00 & 7.66 & 0.21 & 0.14 & 251 \\
\hline $2006-07$ & 0.06 & 0.00 & 0.16 & 0.04 & 227 \\
\hline $2005-06$ & 3.20 & 0.00 & 0.09 & 0.00 & 61 \\
\hline 2004-05 & 1470.61 & 826.62 & 2.08 & 0.50 & 209 \\
\hline 2003-04 & 0.00 & 0.00 & 139.07 & 119.77 & 62 \\
\hline
\end{tabular}

Source: Compiled from BSE Website

Table 15: Number of contracts traded at BSE in Future segment

\begin{tabular}{|c|c|c|c|}
\hline Year & $\begin{array}{c}\text { Index Futures } \\
\text { Contracts }\end{array}$ & $\begin{array}{c}\text { Equity } \\
\text { Futures } \\
\text { Contracts }\end{array}$ & Trading Days \\
\hline $2013-14$ & 42440004 & 1958052 & 247 \\
\hline $2012-13$ & 14146668 & 652684 & 241 \\
\hline $2011-12$ & 7073334 & 326342 & 249 \\
\hline $2010-11$ & 5613 & 0 & 255 \\
\hline $2009-10$ & 3744 & 8 & 224 \\
\hline $2008-09$ & 495830 & 299 & 243 \\
\hline $2007-08$ & 7157078 & 295117 & 251 \\
\hline $2006-07$ & 1638779 & 142433 & 227 \\
\hline $2005-06$ & 89 & 12 & 61 \\
\hline $2004-05$ & 44630 & 6725 & 209 \\
\hline $2003-04$ & 103777 & 33437 & 62 \\
\hline
\end{tabular}

Source: Compiled from BSE Website

Table 16: Number of contracts traded at BSE in Options Segment

\begin{tabular}{|c|c|c|c|c|c|}
\hline Year & $\begin{array}{c}\text { Index Options Call } \\
\text { Contracts }\end{array}$ & $\begin{array}{l}\text { Index Options Put } \\
\text { Contracts }\end{array}$ & $\begin{array}{c}\text { Equity Options Call } \\
\text { Contracts }\end{array}$ & $\begin{array}{c}\text { Equity Options Put } \\
\text { Contracts }\end{array}$ & $\begin{array}{c}\text { Trading } \\
\text { Days }\end{array}$ \\
\hline $2013-14$ & 28387467 & 278474689 & 5425 & 39584 & 247 \\
\hline $2012-13$ & 14413028 & 143044388 & 3498 & 15314 & 241 \\
\hline $2010-11$ & 0 & 10 & 0 & 0 & 255 \\
\hline $2009-10$ & 5276 & 0 & 0 & 0 & 224 \\
\hline 2008-09 & 251 & 122 & 0 & 0 & 243 \\
\hline 2006-07 & 2 & 0 & 5 & 1 & 227 \\
\hline 2005-06 & 100 & 0 & 2 & 0 & 61 \\
\hline 2004-05 & 48065 & 27210 & 72 & 17 & 209 \\
\hline 2003-04 & 0 & 0 & 3466 & 2544 & 62 \\
\hline
\end{tabular}

Source: Compiled from BSE Website

Table 17: Average Daily Turnover at BSE in all segment

\begin{tabular}{|c|c|c|c|c|}
\hline Year & $\begin{array}{c}\text { Total } \\
\text { Contracts }\end{array}$ & $\begin{array}{c}\text { Total } \\
\text { Turnover } \\
\text { (Rs. Cr.) }\end{array}$ & $\begin{array}{c}\text { Average } \\
\text { Daily } \\
\text { Turnover } \\
\text { (Rs. Cr.) }\end{array}$ & $\begin{array}{c}\text { Tra } \\
\text { ding } \\
\text { Day } \\
\text { s }\end{array}$ \\
\hline $2013-14$ & 698497492 & 127464748 & 128344.60 & 247 \\
\hline $2012-13$ & 300067817 & 6884370.9 & 60828.43 & 241 \\
\hline $2011-12$ & 32222825 & 808475.99 & 3246.89 & 249 \\
\hline $2010-11$ & 5623 & 154.33 & 0.61 & 255 \\
\hline $2009-10$ & 9028 & 234.06 & 1.04 & 224 \\
\hline $2008-09$ & 496502 & 11774.83 & 48.46 & 243 \\
\hline $2007-08$ & 7453371 & 242308.41 & 965.37 & 251 \\
\hline
\end{tabular}




\begin{tabular}{|c|c|c|c|c|}
\hline $2006-07$ & 1781220 & 59006.62 & 259.94 & 227 \\
\hline $2005-06$ & 203 & 8.78 & 0.14 & 61 \\
\hline $2004-05$ & 531719 & 16112.32 & 77.09 & 209 \\
\hline $2003-04$ & 143224 & 5021.81 & 81.00 & 62 \\
\hline
\end{tabular}

Source: Compiled from BSE Website

\section{SECTION - IV}

Status of Indian derivatives market vis-à-vis global derivatives market

The derivative segment has expanded in the recent years in substantial way both globally as well as in the Indian capital market. The figures revealed by "world federation of exchanges (WFE)" website to compare the trading figures of 14 selected stock exchanges of America (four exchanges), Asia Pacific (seven exchanges) and EAME (three exchanges) region. Which are summarily specifies in Table No.18, Table No.19, Table No.20 and Table No.21 related to the number of contracts traded and notional value since 2003 to 2012 . These tables show the Indian segment has expanded phenomenally as compared to the global segment. The Notional value of NSE options is 354648.1941 lakhs USD and number of contracts are 67458468 and the notional value at NSE futures is 39228.38563 lakhs USD and number of contracts are 7815624 in 2012 which are so more in compare of 2003. These figures are displaying a more than six to seven times increase over the 10 years period. In case of BSE, the notional value of BSE options is 56993.49322 lakhs USD and number of contracts are 10937357 and the notional value of BSE future is 856.1076879 lakhs USD and number of contracts are 163740 upto Sep. 2012 at global level the increase is less. While Korea, NYSE Euronext (Europe). Hongkong, Tokyo are growing fast in global level, other exchanges are also following at global level which are shown in followings tables:

Table 18: Global trend in Notional value of futures trading (Unit of currency: 000000 USD)

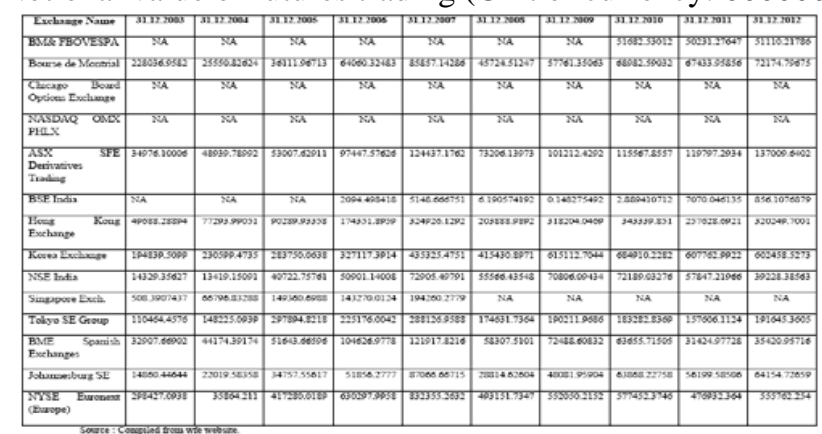

Table 19: Global trends in Number of contracts traded in future trading

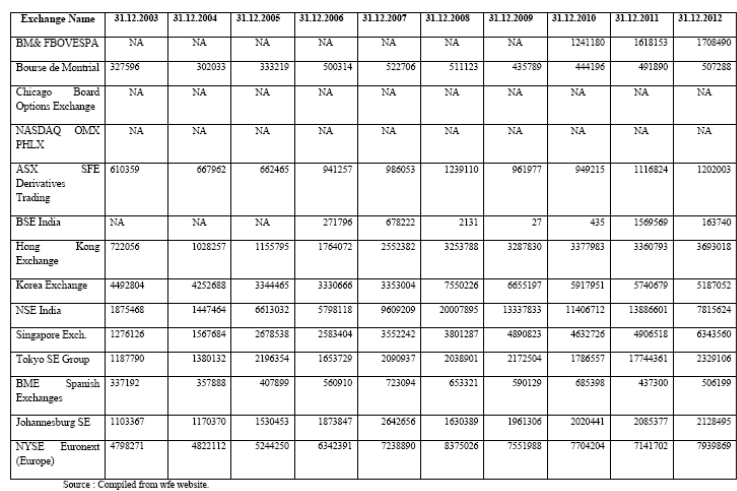

Table 20: Global trend in National value of Option Trading (Currency: 000000 USD) 


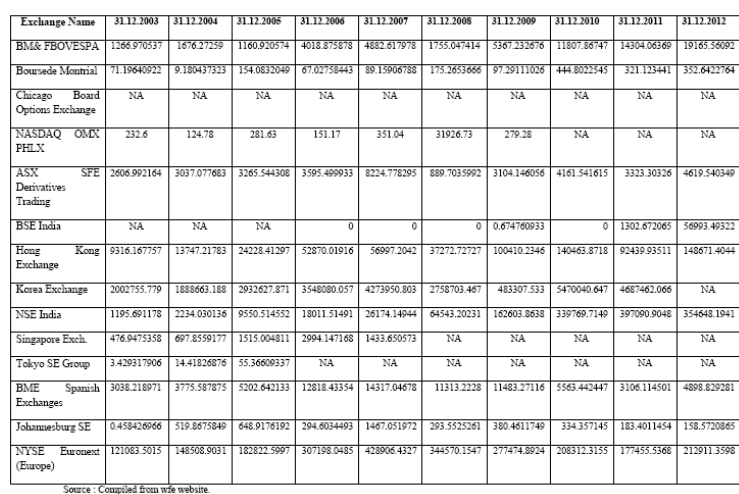

Table 21: Global trend in Number of contract traded in options trading

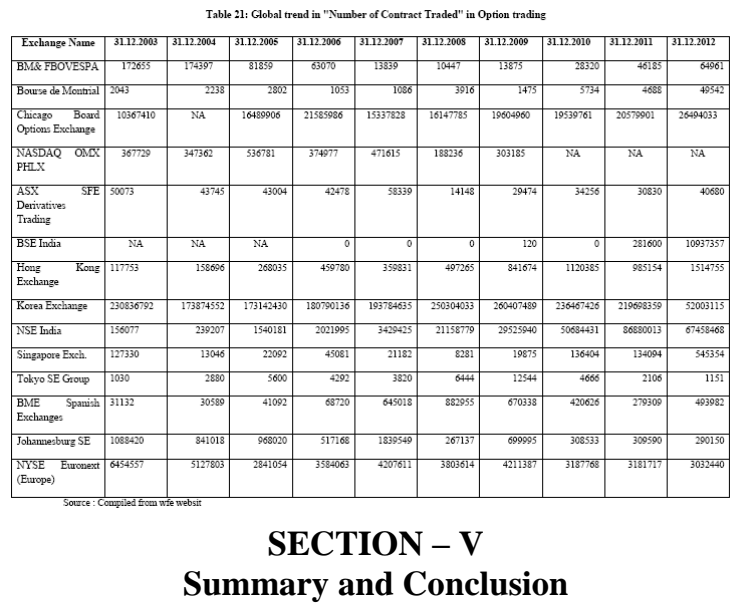

Financial derivatives have earned a well deserved extremely significant place among all the financial instruments (products), due to innovation and revolutionized the landscape. Derivatives are tool for managing risk. Derivatives provide an opportunity to transfer risk from one to another. Launch of equity derivatives in Indian market has been extremely encouraging and successful. The growth of derivatives in the recent years has surpassed the growth of its counterpart globally.

The Notional value of option on the NSE increased from 1195.691178 lakhs USD in 2003 to 354648.1941 lakhs USD in 2012 and notional value of NSE futures increased from 14329.35627 lakhs USD in 2003 to 39228.38563 lakhs USD in 2012. India is one of the most successful developing country in terms of a vibrate market for exchange-traded derivatives. The equity derivatives market is playing a major role in shaping price discovery. Volatility in financial asset price, integration of financial market internationally, sophisticated risk management tools, innovations in financial engineering and choices at risk management strategies have been driving the growth of financial derivatives worldwide, also in India. Finally we can say there is big significance and contribution of derivatives to financial system.

\section{References:}

[1]. A. Vashishtha, S. Kumar, "Development of financial derivatives market in India-a case study", www.eurojounals.com (accessed on 20 February, 2014)

[2]. B. Brahmaiah and Rao P. Subba, "Financial futures and option", 1st ed., Himalaya Publishing House, New Delhi, 1998, PP.25-147.

[3]. D. Vasant, "The Indian financial system and development", 4th ed., Himalaya Publishing House, New Delhi, 2012, PP.398-412, 645677.

[4]. John C. Hull, "Futures and options markets", 2nd ed., PHI Learning Private Ltd., New Delhi, 2009, PP.1-169.

[5]. M. Gurusamy, and J. Sachin, "Financial derivatives", 1st ed., Ramesh Book Depot, New Delhi, 2009-10, PP.1.01-5.10.

[6]. M. Ranganatham and R. Madhumathi, "Security analysis and portfolio management", 1st ed., Pearson education, New Delhi, 2011, PP.723-730.

[7]. N.P. Tripathy, "Financial Services", 3rd Pr., PHI Learning Pvt. Ltd., New Delhi, PP.261-282.

[8]. R.P. Rustagi, "Investment analysis and portfolio management", 1st ed., Sultan Chand \& Sons, New Delhi, 2007, PP.459-596.

[9]. Robert M. Hayes (2002), "Financial derivatives" available at: http://Polaris.gseis.usla.edu/rhaes/ courses/other/financial\%20 derivatives.ppt. (accessed on February 20, 2014)

[10]. S. Kevin, "Security analysis and portfolio management", 6th Pr., PHI Learning Private Ltd., New Delhi, 2009, PP.232-270.

[11]. S.L. Gupta, "Financial derivatives", 6th Pr., PHI Learning Private Ltd., New Delhi, 2009, PP.3-551.

[12]. S.S.S. Kumar, "Financial derivatives", 2nd Pr., PHI Learning Private Ltd., New Delhi, 2008, PP.1-27, 57-306. 
[13]. 'Statistics (time series) at wfe', available at : www.worldexchange.org/statistics (accessed on February, 22-25 2013)

[14]. 'Trading statistics of derivatives segment at BSE', available at: www.bseindia.com (accessed on February 20, 2014)

[15]. V.A. Avadhani, "Security analysis and Portfolio management", 10th ed., Himalaya Publishing House, New Delhi, PP.222-231, 251256.

[16]. V. Gangadhar, G. Ramesh Babu, "Investment management", 1st rep., Anmol Publication Pvt. Ltd., 2006, PP.437-465. 